\title{
BLOOD WILL TELL
}

BY TOM EASTON \& JACK MCDEVITT

A ndy Pharon didn't know why he spent an hour every morning on FaceBook. Scandal! Outrage! Funny pussycats! More outrage! He might have been reading a tabloid, except that FaceBook was more respectable. Which mattered, as he was in Larry's. Martha came over. "Everything okay, Andy?"

"Excellent." He gave her his standard thumbs-up.

He was relieved moments later when his e-mail dinged. Sarah Mills, chief development officer at BioFutures Labs, wanted more ideas. Meeting at 10. Be there!

He finished his sweet roll and sipped his coffee. More ideas. He had nothing, but he couldn't say that, could he?

That was when the old guy with the roller bag squeezed between tables and stopped beside his chair. He was too well dressed to be a drifter but Andy still shook his head as he turned away for another sip of coffee.

"I thought I remembered this place," the guy said. "Came here every morning for five years."

Andy concentrated on his coffee cup and said nothing. Give 'em an inch, and they'll take a mile. Ten miles.

The guy looked down at him. "Hi, Andy. How's it going?"

"You know my name?"

"Sure. I’m you."

"What?" His face was lined and seamed, age spots, hardly any hair. Fifty years older than Andy. "Would you please go away?"

"We'll get time travel in about 30 years." He smiled. "I need a favour."

If this had been an e-mail, he would have hit delete. "Go away, gramps!"

The guy sighed. "I knew you would react that way. That I would. That I had. But I'm not a scammer. I don't want your money. And I already have your ID." He pulled out a chair and lowered himself into it. Then he produced a wallet. "See?"

Driver's licence. His picture with the name Andrew Pharon. Birth date was correct. Issue date: 2072. That would make him over 80 .

Andy stared at him. The guy was smiling.

$\rightarrow$ NATURE.COM Follow Futures: y @NatureFutures $f$ go.nature.com/mtoodm "What do you want?" The smile faded. "Some of your blood." Andy sat frozen. Had his life turned into a vampire fantasy?

"Just some plasma, actually."

"Why?"

"Your people are already working on it. Putting young plasma into an old body can turn the clock back."

Andy nodded. If it was true ... "But why me?" Even as he spoke, he knew the answer. His own young plasma would work better than anyone else's. He really was a timetraveller.

Andrew grinned and delivered his standard thumbs-up, removing all doubt.

"Andy!" Martha waved at him. "You gonna be late!"

He waved back. This was one reason he liked Larry's. They cared.

The old guy was still sitting there, waiting for his response. But it was ridiculous. Time travel wasn't possible. "You have got to be pulling my leg."

The guy shook his head. "No. I just need a couple of pints today, and again next week and the week after." He looked at his bag. "The equipment's right here."

"I'm sure it is. But there's no way I'm letting you stick needles in me. And I've got to run." Andy tucked his tablet into his briefcase and stood.

"But ...!" He looked stricken, as if he had never dreamt that his own self would turn him down. "But I'm you! We're even closer than blood kin!"

"Pardon me. I have to leave." Incredibly, the guy was smiling as Andy went out the door.

Andy glanced over his shoulder and headed down the sidewalk, barely noticing the fumes of the remaining gasburners or the fragrance of the vagrant at the corner. The old guy wasn't following him. Thank God. Maybe he should switch coffee shops for a few days. But then the guy might just show up on his doorstep. That would freak the hell out of his girlfriend.

Okay. Now he had to come up with an idea for Sarah.

BioFutures focused on the microbiome. Their last big success was a probiotic ointment for getting rid of acne. Lately they'd been working on figuring out how to manipulate bacteria in the gut to control obesity. They were close, which was why they needed new ideas. Had to keep the pipeline flowing.

Maybe the old guy had something?

Not time travel. But he recalled reading something about plasma and ageing. It wouldn't take long to check.

Once in the building, he went directly to his cube and started the search. And yes, they were working on it, testing it on people and making slow progress. The idea went back a century, when someone spliced the veins of a young mouse and an old mouse together. The old one got perkier, healthier, younger. The young one aged.

And plasma could be frozen.

He almost laughed.

It took him an hour to write the proposal. Start with some research into whether one's own young plasma is really better than a stranger's. Use mice, where the difference between young and old isn't great. If it checks out, then start collecting plasma, freeze it, store it, and when the donor turns into an old guy ...

He thought Sarah would like it. It was the perfect business plan, complete with references and links. Sell a promise, much like the old cryonics scam. Collect the money now, and worry later about whether the product actually works. Although this one seemed much more likely to be a success than cryonics ever had.

He would be among the very first to bank his plasma. And his older self knew how it had worked out. No wonder he'd sat there smiling when Andy walked out.

Tom Easton is a retired theoretical biologist who has written science-fiction novels and criticism and edited anthologies in addition to more academic work. Jack McDevitt is a prolific, award-winning novelist with an abiding interest in alien contact. $A$ Philadelphia native, he has been, among other things, a naval officer, an English teacher and a management trainer for the US Customs Service. 